\title{
ПОЛІТОЛОГІЧНІ АСПЕКТИ РЕАЛІЗАЦІЇ СТРАТЕГІЇ СВРОІНТЕГРАЦІЇ УКРАЇНИ: ПІДХОДИ ТА МОДЕЛІ
}

\begin{abstract}
Стаття присвячена обтрунтуванню політологічний особливостей реалізачії Стратегї євроінтеграції України на основі різних підходів і моделей. На основі аналізу звітів Кабінету Міністрів Украйни про виконання умов Угоди про асочүіаџію «Украӥна-Свропейський Союз» (УА) з моменту ії підписання у 2014 рочі визначені проблеми за двадиятьма чотирма напрямками, у тому числі й 3 врахуванням політологічних аспектів. Визначено, щуо на сьогодні практично немає сфери сочіальноекономічного розвитку України, які б не були охоплені євроінтеграційними прочесами та перелік питань порядку денного Україна-СС постійно розширюється. Із застосуванням методу графів встановлена пріоритетність циих проблем в розрізі напрямів реалізації завдань Угоди про асоціацію. На основі побудованих моделей $і$ коефіцієнтів еластичності здійснена кількісна оцінка ефективності реалізації стратегічних завдань в рамках Угоди для Украйни. В статті побудовано ієрархічну структуру проблем успішної реалізації Украӥною Угоди про асоціацію та змодельовані перспективи сталого розвитку в результаті вирішення пріоритетних проблем реалізаціі Угоди. Аргументовано пріоритетність політичних та політологічних аспектів реалізачії завдань України в рамках Угоди для підвищення рівня позитивного ефекту співпраці з СС та сталого розвитку країни. Концептуально виділено три основні підходи до адаптації: мінімальний, помірний і максимальний. Ефекти в залежності від обраного підходу до адаптації для сталого розвитку країни можуть мати різний характер в залежності від переслідуваних иілей Украӥни, інституиійної спроможності та рівня соціально-економічного розвитку краӥни. Емпірично обтрунтована найбільш ефективна стратегія інтеграчії в ЄС залежно від рівня адаптації на сучасному етапі соціально-економічного розвитку України. Доведено, щзо є потреба у дослідженні та оцінки поетапної реалізації стратегічних завдань УА саме з точки зору формування політик управління різними галузями через врахування політологічних аспектів. Це дозволить емпірично оцінити відповідність конкретної стратегї адаптаџії намої країни до стандартів СС в межах короткострокового планування і довгострокового планування (стратегування) реалізації запланованих завдань і політологічного ефекту їх впливу на розвиток Украӥни.
\end{abstract}

Ключові слова: Угода про асоиіаџію «Украйна-Свропейський Союз, євроінтеграчія, політологічні аспекти стратегії адаптації, співпраця, соціально-економічний розвиток, сталий розвиток.

Е.Л. ДУРМАН

Херсонский национальный технический университет ORCID: 0000-0001-7829-9944

Н.А. ДУРМАН

Херсонский национальный технический университет ORCID: 0000-0002-3775-205X

\section{ОБОСНОВАНИЕ ОСОБЕННОСТЕЙ И ОПРЕДЕЛЕНИЯ ЭФФЕКТИВНОЙ СТРАТЕГИИ ЕВРОИНТЕГРАЦИИ УКРАИНЫ}

Статья посвящена обоснованию политологических особенностей реализации Стратегии евроинтеграчии Украины на основе разных подходов и моделей. На основе анализа отчетов Кабинета Министров Украины об исполнении условий Соглашения об ассоциащии «Украина-Европейский Союз» с момента его подписания в 2014 году определены проблемы по двадиати четырем направлениям, в том числе и политологическому. Определено, что на сегодняшний день практически нет одной сферь сочиально-экономического развития Украины, которая бы не была охвачены еврочнтеграционными прочессами и перечень вопросов повестки дня Украина-ЕС постоянно расширяется. С использованием метода графов установлена приоритетность этих проблем в разрезе направлений реализации задач Соглашения об ассочичации. На основе построенных моделей и коэффициентов эластичности произведена количественная оценка эффективности реализации стратегических задач в рамках Соглашения для Украины. В статье построена иерархическая структура проблем успешной реализачии Украиной Соглашения об ассоциации и смоделированных перспектив устойчивого развития в 
результате решения приоритетных проблем реализации Согламения. Аргументирована приоритетность политических и политологических аспектов реализачии задач Украины в рамках Соглашения для повышения уровня положительного эффекта сотрудничества с ЕС и устойчивого развития страны. Концептуально выделень три основных подхода $\kappa$ адаптации: минимальный, умеренный и максимальный. Эффекты в зависимости от выбранного подхода к адаптации для устойчивого развития страны могут носить разный характер в зависимости от преследуемых целей Украины, институциональной состоятельности и уровня сочииально-экономического развития страньл. Эмпирически обоснована наиболее эффективная стратегия интеграчии в ЕС в зависимости от уровня адаптации на современном этапе сочиально-экономического развития Украинь. Доказано, что есть необходимость в исследовании и оценке поэтапной реализачии стратегических задач Соглашения именно с точки зрения формирования политик управления разнылми отраслями через учет политологических аспектов. Это позволит эмпирически оценить соответствие конкретной стратегии адаптации нашей страны к стандартам ЕС в пределах краткосрочного планирования и долгосрочного планирования реализации запланированных задач и политологического эффекта их влияния на развитие Украинь.

Ключевые слова: Соглашения об ассоциаџии «Украина-Европейский Союз, евроинтеграция, политологические аспекты стратегии адаптаџии, сотрудничество, социально-экономическое развитие, устойчивое развитие.

O. DURMAN

Kherson National Technical University ORCID: 0000-0001-7829-9944

M. DURMAN

Kherson National Technical University ORCID: 0000-0002-3775-205X

\section{SUBSTANTIATION OF THE FEATURES AND DETERMINATION OF AN EFFECTIVE STRATEGY EUROPEAN INTEGRATION OF UKRAINE}

The article is devoted to the substantiation of political science features of the implementation of the Strategy of European Integration of Ukraine on the basis of different approaches and models. Based on the analysis of the reports of the Cabinet of Ministers of Ukraine on the implementation of the Agreement on the Association "Ukraine-European Union" since its signing in 2014, identified problems in twenty-four areas, including political science. It has been determined that today there is practically no sphere of socio-economic development of Ukraine that would not be covered by European integration processes and the list of issues on the Ukraine-EU agenda is constantly expanding. Using the method of graphs, the priority of these problems in terms of areas of implementation of the objectives of the Association Agreement. On the basis of the constructed models and coefficients of elasticity the quantitative estimation of efficiency of realization of strategic tasks within the limits of the Agreement for Ukraine is made. The article builds a hierarchical structure of problems of successful implementation of the Association Agreement by Ukraine and simulated prospects for sustainable development as a result of solving priority problems of implementation of the Agreement. The priority of political and political aspects of the implementation of Ukraine's tasks within the framework of the Agreement for increasing the level of positive effect of cooperation with the EU and sustainable development of the country is argued. Conceptually, there are three main approaches to adaptation: minimum, moderate and maximum. The effects, depending on the chosen approach to adaptation for sustainable development of the country, may be of different nature depending on the goals of Ukraine, institutional stability and the level of socio-economic development of the country. The most effective strategy of integration into the EU depending on the level of adaptation at the present stage of socio-economic development of Ukraine is empirically substantiated. It is proved that there is a need to study and evaluate the phased implementation of the strategic objectives of the Agreement precisely in terms of the formation of policies for the management of different industries through the consideration of political science aspects. This will allow us to empirically assess the compliance of a specific strategy of adaptation of our country to EU standards within the short-term planning and long-term planning of the planned tasks and the political impact of their impact on the development of Ukraine.

Key words: Agreements on the association "Ukraine-European Union, European integration, political adaptation strategy, cooperation, socio-economic sustainable development.

\section{Постановка проблеми}

За роки незалежності українською владою прийнято низку законодавчих і підзаконних актів, укладено чимало багатосторонніх і двосторонніх угод, держава стала членом багатьох міжнародних організацій. Набуття Україною повноправного членства в СС проголошується стратегічною метою, а отримання статусу - головним зовнішньополітичним пріоритетом держави. 2005-й рік залишив помітні 
віхи в процесі реалізації європейських та євроатлантичних інтеграційних устремлінь України. Це, наприклад, надання Свропейським Союзом Україні статусу країни з ринковою економікою [1].

Стрижнем стратегії економічного та соціального розвитку на період до 2015 р. повинно було стати створення реальних передумов розв'язання основного геополітичного завдання нашої держави вступу України до Європейського Союзу (СС). На думку авторів дослідження «Стратегії економічного і соціального розвитку України (2004-2015 роки) «Шляхом Свропейської інтеграції», ця мета мала стати додатковим потужним стимулом і каталізатором відповідних соціально-економічних та політичних перетворень, i, разом зі вступом України до Світової організації торгівлі (СОТ) та формуванням взаємовигідних відносин 3 партнерами по СНД (Співдружність незалежних держав), мала стати чинником, який зміцнить економічний потенціал, виведе національну економіку на якісно новий рівень.

Після подій 2013-2014 років (відмова Президента В. Януковича від підписання Угоди про асоціацію Україна-СС, другий Майдан, події на сході України та анексія Криму тощо) Україна змінила принципи свого стратегічного розвитку та спрямувала погляди на ЄС, дистанціонувавшись від СНД та Митного Союзу. I вже у підписаній 2015 року Стратегії сталого розвитку «Україна-2020» [2] вказувалося, що метою Стратегії є впровадження в Україні європейських стандартів життя та вихід України на провідні позиції у світі.

Незабезпечення паритетності, зміна пріоритетів та інтересів призвели до того, що у 2018 році був підписаний Указ Президента України про остаточне припинення участі України в роботі статутних органів Співдружності Незалежних Держав та про припинення дії для України окремих міжнародних договорів, укладених у рамках Співдружності Незалежних Держав [3]. Цей же підхід був підтриманий і в 2019 році прийняттям Закону України «Про внесення змін до Конституції України (щодо стратегічного курсу держави на набуття повноправного членства України в Європейському Союзі та в Організації Північноатлантичного договору)» [4].

Зовнішньополітичні пріоритети, оголошені президентом $\mathrm{B}$. Зеленським на зустрічі 3 Президентом Європейської Комісії Жан-Клодом Юнкером, залишаються без змін - ЄС та НАТО [5]. Ці переговори, під час яких було також обговорене широке коло питань взаємодії України та Європейського Союзу, засвідчили обопільну зацікавленість сторін у подальшій розбудові співпраці за всіма напрямами, що становлять взаємний інтерес. Це також підтвердив і міністр закордонних справ В. Пристайко на зустрічі з Високим представником СС із закордонних справ і безпекової політики Жозепом Боррелєм [6].

Три складові - Угода про асоціацію, Копенгагенські критерії та Цілі сталого розвитку - $\epsilon$ надійним дороговказом успішного довгострокового розвитку України, забезпечення добробуту та процвітання усіх громадян. Тому маємо на меті більш детально розглянути здобутки щодо виконання Угоди про асоціацію, у тому числі й їх політологічних аспектів.

3 моменту підписання у 2014 році Угоди про асоціацію «Україна-ЄС» Україна досягла значного прогресу в реформуванні соціально-економічного і політичного життя. Реформування економічних відносин та реалізація заходів, спрямовані на створення поглибленої і всеосяжної зони вільної торгівлі, сприяли зростанню обсягів експорту українських товарів до ЄС на 60\% за період 2014-2020рp. За цей же період в 2 рази зросла кількість підприємств, технології виробництва, які відповідають європейським стандартам і які мають право на експорт продукції в СС [7]. За результатами реформи децентралізації територіальні громади, що об’єдналися (добровільно чи внаслідок рішень Уряду) зібрали на $122 \%$ більше місцевих податків, ніж до об'єднання, знизилася частка витрат на утримання органів місцевого самоврядування в структурі витрат місцевих бюджетів на $12 \%$ і частка витрат на оплату праці на $4 \%$, зросли витрати на розвиток місцевої інфраструктури на 46-569\% [8].

На сьогодні практично немас сфери соціально-економічного розвитку України, які б не були охоплені євроінтеграційними процесами та перелік питань порядку денного Україна-СС постійно розширюється. На ряду зі значними досягненнями, залишається ряд проблем, які стримують розвиток євроінтеграції.

\section{Аналіз останніх досліджень і публікацій}

Дослідженню теорії і практики інтеграції України до ЄС відводилось чільне місце у працях багатьох вітчизняних вчених. Окремі проблеми державної політики України у сфері євроінтеграції висвітлено у роботах таких вчених у галузі державного управління, як: С. Андрейчук, І. Грицяк, Г. Дмитренко, Ю. Кальниш, Є. Коваленко, О. Кривцова, М. Лахижа, І. Лопушинський, Л. Пісьмаченко, Р. Сторожук та інших.

\section{Формулювання мети дослідження}

Метою статті $є$ вивчення політологічних аспектів євроінтеграційних процесів на основі різних підходів та моделей та визначення ефективної стратегії євроінтеграції України.

\section{Виклад основного матеріалу дослідження}

Одним із основних сучасних пріоритетів державної політики України, закріпленим в Конституції України [9], є досягнення повноправного членства країни в Свропейському Союзі (СС). Як показують результати численних досліджень і опитувань понад 60\% громадян підтримують вступ України до ЄС i 
чисельність прихильників інтеграції з кожним роком зростає [10]. Україна знаходиться лише на початковому етапі інтеграційного процесу. Ми маємо асоційовану взаємодію ( з 2014 р.), коли Україна і

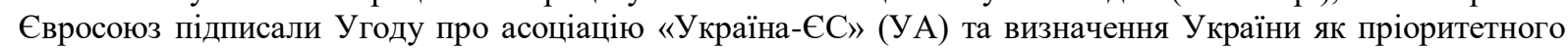
партнера для $\mathrm{CC}[11]$.

Концептуально можна виділити три основні підходи до стратегії адаптації: мінімальна, помірна і максимальна. Для мінімальної інтеграції характерним $\epsilon$ позасистемний характер, тобто чітко простежується необхідність задоволення кон'юнктурних запитів сторін, які склалися на даний відрізок часу. Стратегія помірної інтеграції передбачає створення зони вільної торгівлі з $Є С$, поширення деяких інших переваг внутрішнього ринку ЄС. Грунтується на баченні з боку Європейської Комісії майбутніх перспектив відносин зі своїми сусідами, в тому числі і з Україною. Максимальна адаптація є принципово новою для українського адаптаційного процесу і передбачає повноправне членство в ЄС. Ефекти в залежності від обраної стратегії адаптації для сталого розвитку країни можуть мати різний характер в залежності від переслідуваних цілей України, інституційної спроможності та рівня соціальноекономічного розвитку країни.

Першочерговим завданням дослідження стало визначення пріоритетних проблем реалізації УА на основі аналізу звітів Кабінету Міністрів України [6] про виконання зобов'язань УА за 2014-2020 pр. в контексті 24 напрямків та виокремлення серед них тих, що мають політологічний аспект. Серед цих напрямків можна виокремити мінімум 8 , які отримують прямий вплив з боку політичних процесів, хоча й ті, що залишилися теж «зав'язані» на формування та реалізацію відповідних політик.

До таких напрямків відносяться: енергетика (ENER); юстиція, свобода, безпека і права людини (JUST); технічні бар'єри в торгівлі (TRADE); підприємництво (ENT); політичний діалог, національна безпека і оборона (POLIT); оподаткування (TAX); освіта, молодь, навчання (EDUC); гуманітарна політика (HUM); сільське господарство (AGR); наука, технології та інновації, космос (SCIEN); фінансовий сектор (FIN); державні закупівлі (PUR); соціальна політика і трудові відносини (SOC); статистика і обмін інформацією (STAT); транспорт, транспортна інфраструктура, поштові та кур'єрські послуги (TRANS); енергоефективність та житлово-комунальне господарство (UTIL); управління державними фінансами (PUB.FIN); навколишне середовище та цивільний захист (ENVIR); санітарні і фітосанітарні заходи (SANIT); захист прав споживачів (CONS); фінансове співробітництво і боротьба 3 шахрайством (FRAUD); цивільне здоров'я (HEAL); митні питання (CUST); інтелектуальна власність (INTEL).

Для встановлення пріоритетності проблем реалізації завдань УА використовувався метод графів. Зазначені напрями реалізації УА виступили вершинами орієнтованого графа, побудованого для встановлення пріоритетності проблем. Дугами графа - напрями впливу між вершинами, встановлене на основі теоретичного аналізу. При цьому напрямок дуги графа визначено як сукупність впливу всіх проблем в рамках одного напряму реалізації УА. Під пріоритетними розумілися першочергові проблеми, без вирішення яких не можлива успішна реалізація УА.

За допомогою інструментарію нейронних мереж здійснено моделювання перспектив сталого розвитку України з урахуванням рішення пріоритетних проблем, які сформували 1-й рівень ієрархії. УА орієнтоване на досягнення цілей сталого розвитку [12]. Залежними змінними моделей виступили показники: GDP per сарita, виражений в тис. дол. США, The Legatum Prosperity Index, Human Development Index (як показники соціально-економічного розвитку) і Environmental Performance Index (як показник екологічного розвитку), що відображає концепцію сталого розвитку [13].

При використанні методу графів (визначення вершин) і моделюванні перспектив сталого розвитку країн (визначення незалежних змінних) використовувалися не конкретні проблеми, а їх сукупність в рамках кожного напрямку згідно зі звітом про виконання УА України [12]. Незалежними змінними моделі виступили показники загального прогресу виконання зобов'язань за напрямками, які сформували 1-й рівень ієрархії. Під загальним прогресом розуміється питома вага виконання взятих Україною обов'язків по УА на період до 2024 р в рамках кожного напряму, на дату аналізу з початку дії УА (червень 2014 г.) [12]. Досягнення цілей сталого розвитку залежить не тільки від ефективності управління, а також від наявності фінансування, яке відповідно до [14] $є$ базовим чинником, які забезпечують сталий розвиток. Тому, інша група незалежних змінних представлена базисними темпами зростання обсягів фінансування: державних видатків за напрямами фінансування (Е), капітальних інвестицій (CI), прямих іноземних інвестицій (FDI), фінансування виконання УА з боку ЄC (F). Темпи росту розраховані на основі обсягів фінансування, виражених в доларах США, відносно 2005 г. При розрахунку показника $\mathrm{F}$ базою порівняння виступив 2015 p

У дослідженні використовувалися нейронні мережі типу багатошаровий перцептрон і метод зворотнього поширення помилки для визначення ваг синапсів нейронної мережі: 


$$
\begin{aligned}
& \mathrm{y}=\mathrm{f}(\mathrm{Ag}, \text { Fin })=\mathrm{f}\left(\mathrm{W}^{\wedge}((\mathrm{n}-1)) \cdot \mathrm{H}^{\wedge}((\mathrm{n}-1))+\mathrm{B}^{\wedge}((\mathrm{n}-1))\right) \\
& \mathrm{Ag}=\left\{\mathrm{P}(\text { Ag_i })=\mathrm{R}(\text { Ag_i }) \cap \mathrm{P}\left(\mathrm{Ag} \_\mathrm{i}\right)\right\}
\end{aligned}
$$

де $\quad$ - залежна змінна, яка відноситься до показників сталого розвитку (GDP per capita, The Legatum Prosperity Index, Human Development Index, Environmental Performance Index);

Ag, Fin - незалежні змінні;

Fin - показники динаміки об'ємів фінансування (E, CI, FDI, F);

$\mathrm{Ag}$ - показники прогресу виконання Україною зобов'язань у співвідношенні із Угодою про Асоціацію «Україна-СС» за напрямками, які сформували 1-ий рівень ієрархії проблем реалізації Угоди;

P(Agi) - підмножина вершини-попередниці, від яких за орієнтованим графом існує шлях, який приводить до вершини Agi;

R(Agi) - підмножина вершини досяжності - вершини, до якої, згідно орієнтованому графу, існує шлях від вершини Agi;

W - вектор важелів синапсів нейронної мережі;

Н - вектор вихідних імпульсів;

В - вектор шуму.

Для побудови нейронних моделей в програмі Statistica 12.0 використовувались щорічні дані за період 2005-2020 pр. У моделях, де залежними змінними виступили GDP per capita i Human Development Index, використаний період становить 1993-2020 (у цьому випадку базою для розрахунку темпів зростання обсягів фінансування використано 1993 р.).

На основі опитуваних взаємозв'язків між проблемами реалізації УА побудований орієнтований граф (рис. 1) та визначено рівні ієрархії проблем.

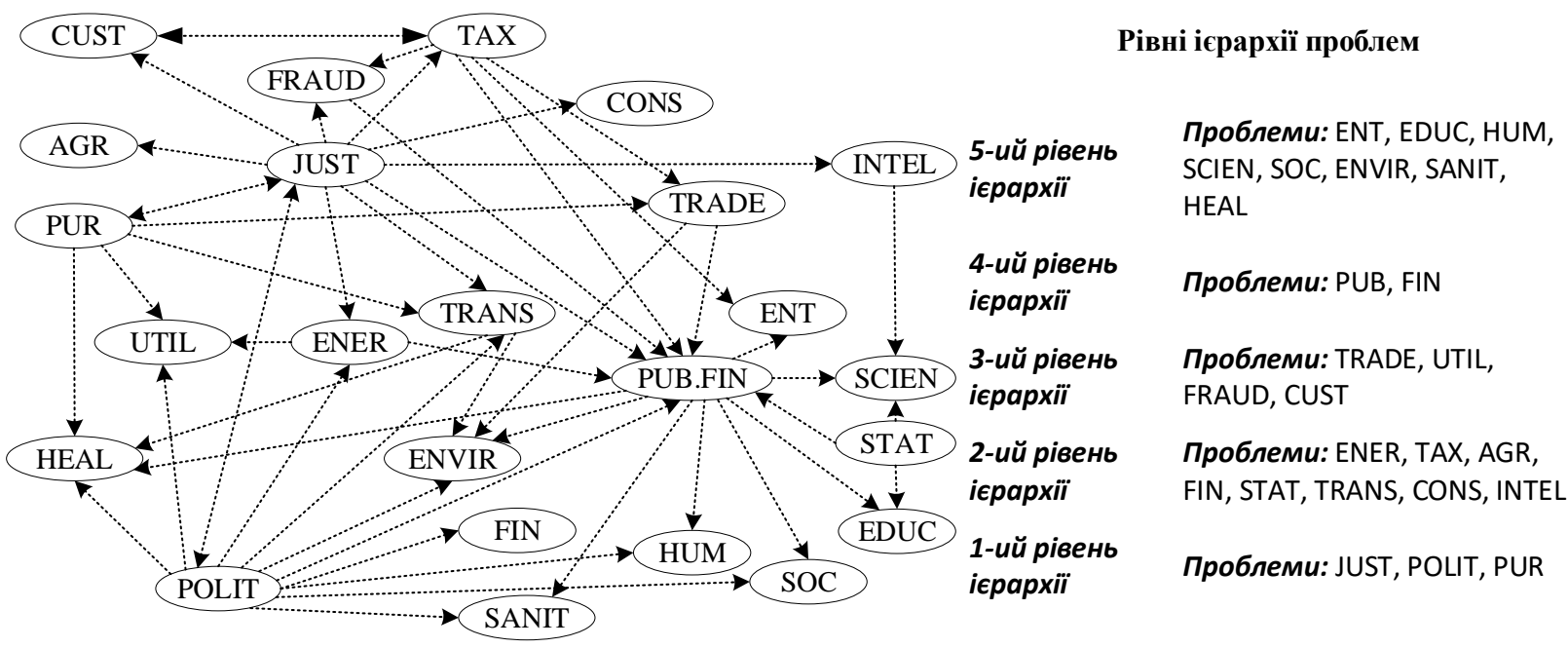

Рис. 1. Ієрархічна модель проблем успішної реалізації Україною УА

Згідно побудованої моделі, на 1-му рівні ісрархії сформовані проблеми, які стримують реалізацію УА за напрямками «юстиція, свобода, безпека і права людини» (JUST), «політичний діалог, національна безпека і оборона» (POLIT), «державні закупівлі» ( PUR). Проблеми за цими напрямками $\epsilon$ пріоритетними, без усунення яких неможливе досягнення ефективної співпраці на шляху до євроінтеграції. Проблеми за цими напрямками в першу чергу стосуються військового конфлікту на Донбасі і анексії Криму; високого рівня корупції в Україні; існування ряду нерозкритих злочинів, скоєних співробітниками поліції, іншими правоохоронними і державними особами; законодавчої неврегульованості питань криміналізації контрабанди та захисту персональних даних при використанні штучного інтелекту; дискримінації і загрози корупції в системі державних закупівель. Вказані проблеми формують проблеми за напрямками 2-5 ієрархічних рівнів.

Моделювання перспектив сталого розвитку в результаті вирішення пріоритетних проблем реалізації УА представлено в таблиці 1. 
Таблиця 1

Характеристики нейронних моделей впливу прогресу реалізації на стійкість розвитку України

\begin{tabular}{|c|c|c|c|c|}
\hline \multicolumn{2}{|c|}{ Іерархія моделі } & \multicolumn{3}{|c|}{ Показники адекватності } \\
\hline \multirow{8}{*}{ (-) } & \multirow{8}{*}{$\begin{array}{c}\text { Model type: MLP 6-3-1; } \\
\text { Dependent variable: GDP per } \\
\text { capita; } \\
\text { Independent variables: JUST, } \\
\text { POLIT, PUR, FDI, CI, Eec }\end{array}$} & Training error & \multicolumn{2}{|c|}{0.0002} \\
\hline & & Test error & \multicolumn{2}{|c|}{0.0003} \\
\hline & & Validation error & \multicolumn{2}{|c|}{0.0005} \\
\hline & & \multicolumn{3}{|c|}{ Показники еластичності, \% } \\
\hline & & Переменная & $X_{2016}{ }^{*}$ & $\mathrm{X}_{2020}{ }^{* *}$ \\
\hline & & JUST & 0.27 & 0.22 \\
\hline & & POLIT & 0.19 & 0.17 \\
\hline & & PUR & 0.13 & 0.10 \\
\hline & \multirow{9}{*}{$\begin{array}{c}\text { Model type: MLP 5-4-4-1; } \\
\text { Dependent variable: The Legatum } \\
\text { Prosperity Index; } \\
\text { Independent variables: JUST, } \\
\text { POLIT, PUR, CI, Eec }\end{array}$} & \multicolumn{3}{|c|}{ Показники адекватності } \\
\hline & & Training error & \multicolumn{2}{|c|}{0.0000} \\
\hline & & Test error & \multicolumn{2}{|c|}{0.0001} \\
\hline & & Validation error & \multicolumn{2}{|c|}{0.0003} \\
\hline & & \multicolumn{3}{|c|}{ Показники еластичності, \% } \\
\hline & & Переменная & $\mathrm{X}_{2016}$ & $\mathrm{X}_{2020}$ \\
\hline & & JUST & 0.31 & 0.24 \\
\hline & & POLIT & 0.27 & 0.22 \\
\hline & & PUR & 0.18 & 0.16 \\
\hline \multirow{9}{*}{ (-) } & \multirow{9}{*}{$\begin{array}{l}\text { Model type: MLP 6-3-5-1; } \\
\text { Dependent variable: Human } \\
\text { Development Index; } \\
\text { Independent variables: JUST, } \\
\text { POLIT, PUR, CI, Eec, Es }\end{array}$} & \multicolumn{3}{|c|}{ Показники адекватності } \\
\hline & & Training error & \multicolumn{2}{|c|}{0.0000} \\
\hline & & Test error & \multirow{2}{*}{\multicolumn{2}{|c|}{$\frac{0.0003}{0.0002}$}} \\
\hline & & Validation error & & \\
\hline & & \multicolumn{3}{|c|}{ Показники еластичності, \% } \\
\hline & & Переменная & $\mathrm{X}_{2016}$ & $\mathrm{X}_{2020}$ \\
\hline & & JUST & 0.28 & 0.23 \\
\hline & & POLIT & 0.23 & 0.22 \\
\hline & & PUR & 0.22 & 0.20 \\
\hline \multirow{9}{*}{ O- } & \multirow{9}{*}{$\begin{array}{c}\text { Model type: MLP 4-5-1; } \\
\text { Dependent variable: Environmental } \\
\text { Performance Index; } \\
\text { Independent variables: JUST, } \\
\text { POLIT, PUR, CI }\end{array}$} & \multicolumn{3}{|c|}{ Показники адекватності } \\
\hline & & Training error & \multirow{2}{*}{\multicolumn{2}{|c|}{$\begin{array}{l}0.0001 \\
0.0000\end{array}$}} \\
\hline & & Test error & & \\
\hline & & Validation error & \multicolumn{2}{|c|}{0.0004} \\
\hline & & \multicolumn{3}{|c|}{ Показники еластичності, \% } \\
\hline & & Переменная & $X_{2016}$ & $X_{2020}$ \\
\hline & & JUST & 0.24 & 0.20 \\
\hline & & POLIT & 0.21 & 0.18 \\
\hline & & PUR & 0.20 & 0.17 \\
\hline
\end{tabular}

Еес - темпи зростання обсягів видатків державного бюджету на економічну діяльність;

Es - темпи зростання обсягів видатків державного бюджету на соціальний захист і соціальне забезпечення;

* - значення коефіцієнтів еластичності, що показують зміну результуючого показника при зростанні відповідної незалежної змінної на 1\% щодо ії значення за 2016 р.;

** - значення коефіцієнтів еластичності, що показують зміну результуючого показника при зростанні відповідної незалежної змінної на 1\% щодо її значення за 2020 р

Коефіцієнти еластичності показують змінення залежних змінних при зростанні незалежної на $1 \%$ щодо значення за 2016 і 2020 р. За всіма незалежними змінними, які відповідають напрямкам реалізації УА, спостерігаються позитивні значення показників еластичності. Це свідчить про те, що прогрес у виконанні УА на даному етапі розвитку робить позитивний вплив на можливості сталого розвитку України. Розраховані коефіцієнти парної кореляції між показниками сталого розвитку (GDP per саріta, The Legatum Prosperity Index, Human Development Index, Environmental Performance Index) і показниками прогреса реалізації УА за напрямками (ENER, JUST, TRADE, ENT, POLIT, TAX, EDUC, HUM, AGR, SCIEN, FIN, PUR, SOC, STAT, TRANS, UTIL, PUB.FIN, ENVIR, SANIT, CONS, FRAUD, HEAL, CUST, INTEL) знаходяться в діапазоні 0.66-0.84. Про адекватність побудованих моделей свідчать значення 
Training, Test, Validation error, які не перевищують 5\%. Моделі включають значимі при рівні $\mathrm{p}=0.05$ незалежні змінні, відібрані автоматично в процесі побудови моделі в програмі Statistica 12.0.

На підставі отриманих результатів було засвідчено, що політологічні аспекти реалізації УА в сфері юстиції, свободи, безпеки та права людини; політичного діалогу, національної безпеки і оборони; державних закупівель $є$ пріоритетними. До того ж позитивні значення показників еластичності свідчать про те, що прогрес в реалізації УА з точки зору цього аспекту робить позитивний вплив на можливості сталого розвитку України.

Серед показників фінансування найбільш істотний позитивний вплив на показники сталого розвитку надають темпи зростання капітальних інвестицій, які значимі в усіх моделях. У моделях оцінки впливу на GDP per саріtа значущі ще показники темпів зростання обсягів видатків державного бюджету на економічну діяльність і прямих іноземних інвестицій; в моделі оцінки впливу на The Legatum Prosperity Index - темпи зростання обсягів видатків державного бюджету на економічну діяльність; в моделі оцінки впливу на Human Development Index - темпи зростання обсягів видатків державного бюджету на економічну, на соціальний захист та соціальне забезпечення.

Незважаючи на те, що факторами, що впливають на розвиток людського капіталу, є освіта та охорона здоров'я [15], показники динаміки обсягів державних витрат за цими сферами не є значущими. Це можна пояснити скоріше неефективністю управління державними коштами за цими напрямками. Аналогічна ситуація з показником темпів зростання витрат на охорону навколишнього середовища, який $€$ незначним при оцінюванні впливу на Environmental Performance Index.

Найбільш істотний вплив на показники сталого розвитку надає прогрес у сфері юстиції, свободи, безпеки та права людини. При зростанні загального прогресу в даній сфері на $1 \%$ щодо 2020 р показники сталого розвитку виростають на $0.20-0.24 \%$. Найвищі коефіцієнти еластичності по The Legatum Prosperity Index (0.24\%) i Human Development Index (0.23\%).

Зростання загального прогреса по виконанню Угоди в сфері політичного діалогу, національної безпеки і оборони на $1 \%$ щодо 2020 р призводить до зростання GDP per capita на $0.17 \%$, The Legatum Prosperity Index i Human Development Index на $0.22 \%$, Environmental Performance Index на $0.18 \%$. Прогрес 3 виконання УА в сфері державних закупівель надає менш значущий вплив на можливості сталого розвитку. Зростання показників сталого розвитку можливий на $0.10-0.20 \%$ при зростанні загального прогресу в сфері державних закупівель на $1 \%$ щодо $2020 \mathrm{p}$

Саме тому емпіричним шляхом обгрунтовано, що на сучасному етапі соціально-економічного розвитку найбільш ефективною стратегією інтеграційного процесу України в ЄС є стратегія помірної адаптації. Це можна пояснити тим, що на сьогодні наша країна внутрішньо не відповідає стандартам Європейського союзу. Гомогенність - це ключовий принцип, покладений в основу політики розширення $\in \mathrm{C}$, який передбачає, що країни, які приєднуються до $\mathrm{CC}$, повинні в політичному, економічному i політичному плані відповідати поточним членам.

Позитивні значення коефіцієнтів кореляції за всіма напрямами реалізації УА свідчать про їх стимулюючий і суттєвий вплив на стійкість розвитку економіки України. Окремо слід відзначити політологічні напрямки, які передбачають не тільки адаптацію законодавчої та нормативної бази України відповідно до вимого Європейського Союзу, але й перехід на новий рівень сприйняття його політичної культури як владою, так і населенням, і слугують основою для дальших реформ. Адаптація українського законодавства до законодавства ЄС (що відображає всі сфери соціально-економічного розвитку країни) повинна бути всеосяжною (реалізовуватися в усіх напрямках). Але, разом 3 цим, спостерігається зниження значень показників еластичності з ростом прогресу по виконанню УА. Це означає, що процес зближення з ЄС має бути дозованим і супроводжуватися відповідними державними заходами, спрямованими на нейтралізацію ризиків євроінтеграції, що відповідає концепції «помірної адаптації».

У зв'язку з обмеженістю кількісних показників, що характеризують ступінь реалізації Україною завдань УА, важко в повній мірі оцінити прогрес їх виконання, оскільки змістовність завдань УА відрізняється складністю і комплексністю. Але, тим не менш, такий підхід дозволяє оцінити ефективність реалізації УА на рівні тактичного виконання. Також досліджена і оцінена поетапна реалізація стратегічних завдань УА саме з точки зору формування політик управління різними галузями. Це дозволить емпірично оцінити найбільш повну відповідність конкретної стратегії адаптації нашої країни до стандартів $Є С$ в межах короткострокового планування і довгострокового планування (стратегування) реалізації запланованих завдань і політологічного ефекту їх впливу на розвиток України.

\section{Список використаної літератури}

1. Свропейський Союз та його роль. URL: http://ukrstat.org/uk/nato/program.htm

2. Про Стратегію сталого розвитку «Україна - 2020»: Указ Президента України від 12 січня 2015 року № 5/2015. URL: https://zakon1.rada.gov.ua/laws/show/5/2015

3. Про рішення Ради національної безпеки і оборони України від 2 травня 2018 року «Про 
припинення дії для України окремих міжнародних договорів, укладених у рамках Співдружності Незалежних Держав» : Указ Президента України від 19.05.2018 p. №139/2018. URL: https://www.president.gov.ua/documents/1392018-24202

4. Про внесення змін до Конституції України (щодо стратегічного курсу держави на набуття повноправного членства України в Свропейському Союзі та в Організації Північноатлантичного договору) : Закон України від 7 лютого 2019 року № 2680-VIII. URL: https://zakon.rada.gov.ua/laws/show/2680-19\#n2

5. Президент України Володимир Зеленський зустрівся з Президентом Свропейської Комісії Жан-Клодом Юнкером. URL: https://www.president.gov.ua/news/prezident-ukrayini-volodimir-zelenskijzustrivsya-z-preziden-55761

6. Вадим Пристайко зустрівся з Високим представником $Є С$ із закордонних справ і безпекової політики Жозепом Боррелєм. URL: https://mfa.gov.ua/ua/press-center/news/76422-vadim-pristajkozustrivsya-z-visokim-predstavnikom-jes-iz-zakordonnih-sprav-i-bezpekovoji-politiki-zhozepom-borrelem

7. Report on Implementation of the Association Agreement Between Ukraine and the European Union 2015-2020. $\quad$ Евроінтеграційний портал. $2021 . \quad$ URL: ua.kmu.gov.ua/sites/default/files/inline/files/aa_implementation_report_2015-2020_eng_final.pdf

8. Харус А., Нивьевский О. В единстве есть сила: влияние реформы децентрализации на местные бюджеты в Украине. 2020. URL: https://voxukraine.org/en/in-unity-there-is-strength-the-effect-ofthe-decentralization-reform-on-local-budgets-in-ukraine/

9. Конституція України: Основний Закон України від 28 червня 1996 року. URL: https://zakon.rada.gov.ua/laws/show/254\%D0\%BA/96-\%D0\%B2\%D1\%80\#Text

10. Вступление в ЕС поддерживают более $60 \%$ украинцев, за членство в НАТО - почти $54 \%$. Украинская правда. 2021. URL: https://www.pravda.com.ua/rus/news/2021/06/30/7298949/

11. Association Agreement between the European Union and Ukraine. 2021. URL: https://www.kmu.gov.ua/en/yevropejska-integraciya/ugoda-pro-asociacyu

12. Звіти про виконання Угоди про асоціацію між Україною та ЄС. Урядовий портал. 2020. URL: https://www.kmu.gov.ua/diyalnist/yevropejska-integraciya/vikonannya-ugodi-pro-asociaciyu/zviti-provikonannya-ugodi-pro-asociaciyu

13. Кузьмак О., Кузмак О., Погріщук Б. Сталий розвиток: тенденції та реалії України. Інтернетконференція. 03 травня 2021. 255 c. URL: https://doi.org/10.1051/e3sconf/202125501035

14. Разумовська, Є., Юзвович Л., Князєва Є., Клименко М., Шелякін В. Ефективність політики уряду Росії щодо підтримки МСП у пандемії COVID-19. Відкриті Іннов. Технол. 2020. № 6. 160 с. URL: : https://doi.org/10.3390/joitmc6040160

15. Our World In Data. Human Capital Index vs. GDP per capita. 2021. URL: https://ourworldindata.org/grapher/human-capital-index-vs-gdp

\section{References}

1. Yevropeys'kyy Soyuz ta yoho rol'. URL: http://ukrstat.org/uk/nato/program.htm

2. Pro Stratehiyu staloho rozvytku «Ukrayina - 2020»: Ukaz Prezydenta Ukrayiny vid 12 sichnya 2015 roku № 5/2015. URL: https://zakon1.rada.gov.ua/laws/show/5/2015

3. Pro rishennya Rady natsional'noyi bezpeky i oborony Ukrayiny vid 2 travnya 2018 roku «Pro prypynennya diyi dlya Ukrayiny okremykh mizhnarodnykh dohovoriv, ukladenykh u ramkakh Spivdruzhnosti Nezalezhnykh Derzhav» : Ukaz Prezydenta Ukrayiny vid 19.05.2018 r. №139/2018. URL: https://www.president.gov.ua/documents/1392018-24202

4. Pro vnesennya zmin do Konstytutsiyi Ukrayiny (shchodo stratehichnoho kursu derzhavy na nabuttya povnopravnoho chlenstva Ukrayiny v Yevropeys'komu Soyuzi ta v Orhanizatsiyi Pivnichnoatlantychnoho dohovoru) : Zakon Ukrayiny vid 7 lyutoho 2019 roku № 2680-VIII. URL: https://zakon.rada.gov.ua/laws/show/2680-19\#n2

5. Prezydent Ukrayiny Volodymyr Zelens'kyy zustrivsya z Prezydentom Yevropeys'koyi Komisiyi ZhanKlodom Yunkerom. URL: https://www.president.gov.ua/news/prezident-ukrayini-volodimir-zelenskijzustrivsya-z-preziden-55761

6. Vadym Prystayko zustrivsya z Vysokym predstavnykom YES iz zakordonnykh sprav i bezpekovoyi polityky Zhozepom Borrelyem. URL: https://mfa.gov.ua/ua/press-center/news/76422-vadim-pristajkozustrivsya-z-visokim-predstavnikom-jes-iz-zakordonnih-sprav-i-bezpekovoji-politiki-zhozepom-borrelem

7. Report on Implementation of the Association Agreement Between Ukraine and the European Union 2015-2020. Yevrointehratsiynyy portal. $2021 . \quad$ URL: ua.kmu.gov.ua/sites/default/files/inline/files/aa_implementation_report_2015-2020_eng_final.pdf

8. Kharus A., Nyv'evskyy O. V edynstve est' syla: vlyyanye reformy detsentralyzatsyy na mestnye byudzhety $\mathrm{v}$ Ukrayne. 2020. URL: https://voxukraine.org/en/in-unity-there-is-strength-the-effect-of-thedecentralization-reform-on-local-budgets-in-ukraine/ 
9. Konstytutsiya Ukrayiny: Osnovnyy Zakon Ukrayiny vid 28 chervnya 1996 roku. URL: https://zakon.rada.gov.ua/laws/show/254\%D0\%BA/96-\%D0\%B2\%D1\%80\#Text

10. Vstuplenye v ES podderzhyvayut bolee $60 \%$ ukrayntsev, za chlenstvo v NATO - pochty $54 \%$. Ukraynskaya pravda. 2021. URL: https://www.pravda.com.ua/rus/news/2021/06/30/7298949/

11. Association Agreement between the European Union and Ukraine. 2021. URL: https://www.kmu.gov.ua/en/yevropejska-integraciya/ugoda-pro-asociacyu

12.Zvity pro vykonannya Uhody pro asotsiatsiyu mizh Ukrayinoyu ta YES. Uryadovyy portal. 2020. URL: https://www.kmu.gov.ua/diyalnist/yevropejska-integraciya/vikonannya-ugodi-pro-asociaciyu/zviti-pro-

vikonannya-ugodi-pro-asociaciyu

13. Kuz'mak O., Kuzmak O., Pohrishchuk B. Stalyy rozvytok: tendentsiyi ta realiyi Ukrayiny. Internetkonferentsiya. 03 travnya 2021. 255 p. URL: https://doi.org/10.1051/e3sconf/202125501035

14. Razumovs'ka, YE., Yuzvovych L., Knyazyeva YE., Klymenko M., Shelyakin V. Efektyvnist' polityky uryadu Rosiyi shchodo pidtrymky MSP u pandemiyi COVID-19. Vidkryti Innov. Tekhnol. 2020. № 6. 160 p. URL: : https://doi.org/10.3390/joitmc6040160

15. Our World In Data. Human Capital Index vs. GDP per capita. 2021. URL: https://ourworldindata.org/grapher/human-capital-index-vs-gdp 